\title{
Growth and population assessment of the queen conch Strombus gigas (Mesogastropoda: Strombidae) by capture mark-recapture sampling in a natural protected area of the Mexican Caribbean
}

\author{
Joanne Rebecca Peel \& Dalila Aldana Aranda \\ Centro de Investigación y de Estudios Avanzados del Instituto Politécnico Nacional, Km 6 Antigua Carretera a \\ Progreso, Mérida, Yucatán, México; jrpeel@gmx.de
}

\author{
Received 14-VI-2011. C Corrected 02-XII-2011. Accepted 20-XII-2011.
}

\begin{abstract}
The Inlet of Xel-Ha is used as a park for ecotourism, representing a sanctuary for the conservation of Pink Queen Conch. Increasing fishing pressure has led to the inclusion of the species in CITES. Most knowledge about the growth of the queen conch was generated through aquaculture, ocean enclosures or obtained using estimates derived from population dynamics. In this study we estimated the growth rate of juvenile S. gigas in a natural protected area by direct methods, during the period of April 2009 to January 2011. Data was obtained by capture-mark-recapture sampling. 1418 individuals were tagged and growth of 714 conchs was analyzed. Population size and density was estimated using Schnabel's method. The average density was estimated at $0.1694 \pm 0.0996$ ind. $\mathrm{m}^{-2}$, while the highest density was estimated for September $2010\left(0.3074\right.$ ind. $\left.\mathrm{m}^{-2}\right)$. The highest growth rate $\left(0.27 \pm 0.10 \mathrm{~mm} \mathrm{day}^{-1}\right)$ was detected in juveniles with an initial size between $100-149 \mathrm{~mm}$, followed by conch $<100 \mathrm{~mm}$, with an increase of $0.24 \pm 0.05 \mathrm{~mm}_{\text {day }}{ }^{-1}$. The growth rate decreased for individuals with an initial size between $150-199 \mathrm{~mm}\left(0.18 \pm 0.09 \mathrm{~mm} \mathrm{day}^{-1}\right)$ and for organisms $>200 \mathrm{~mm}(0.08 \pm$ $\left.0.07 \mathrm{~mm} \mathrm{day}^{-1}\right)$. Variability in growth rate was high in conch $100-149 \mathrm{~mm}$ and showed seasonal differences, with the highest growth rate in May 2010. Recruitment of juveniles was highest in October 2009 and February 2010. The population of Xel-Ha has grown in size and more large and juvenile conch could be found than in previous studies, indicating that Xel-ha park is working as a sanctuary for the conservation of the queen conch in Mexico's Riviera Maya. The growth rate of juvenile conch in Xel-Ha is high and exhibits large variations in individuals, reflecting the natural conditions of foraging and aggregation. Seasonal differences in growth rate may be associated with water quality and availability of nutrients for primary production. We conclude that the direct method is useful for the assessment of growth in juvenile $S$. gigas and that growth in natural conditions may be higher than in aquaculture systems. This information may be applied to fishery management as well as rehabilitation programs and aquaculture. Rev. Biol. Trop. 60 (Suppl. 1): 127-137. Epub 2012 March 01.
\end{abstract}

Keywords: Population size, Population density, Growth, Mark-Recapture, Recruitment, Nursery, Xel-Ha.

The queen conch (Strombus gigas Linnaeus, 1758) is a large gastropod which represents an important food and economic resource in the Caribbean, being the second largest fishery after the spiny lobster (Appeldorn 1994) with landings of 6000 metric tons, worth $\$ 60$ million Dollars (Chakalall \& Cochrane 1997). The increasing fishing pressure caused populations to decline in the 1980's and led to the inclusion of this mollusk in the Convention on International Trade of Endangered Species (CITES) and the list of commercially threatened species. In Mexico, on the Peninsula of Yucatan, the conch fisheries reached a peak in 1983, with landings of 1250 tons. In the late 1980's the majority of the stocks were reported to be overexploited, especially in the state of Yucatan where a permanent fishing ban was implemented in 1988 (Baquiero-Cárdenas 1997). In Quintana Roo captures reached their maximum in the early eighties and by the end of the decade catch volumes started to show signs 
of overexploitation (Carta Pesquera Nacional 2006). This has led on one hand to the implementation of different management programs to protect the conch (INP-SAGARPA 2008) and on the other hand, to the development of its aquaculture (Berg 1976, Brownell 1977, Brownell \& Stevely 1981, Rathier 1987, Glazer et al. 1997, Davis 2000, Moreno de la Torre \& Aldana-Aranda 2007). The inlet of Xel-Ha is a natural marine protected area, which has been used since 1995 as a park for ecotourism. The main attraction is the observation of marine fauna in its natural environment; hence the removal of any flora or fauna is prohibited. Xel-Ha is considered a sanctuary for the conservation of the queen conch in the Mexican Riviera Maya, hosting an important number of juvenile conch (Peel et al. 2010).

Sound management of a resource such as $S$. gigas, as well as its rehabilitation, protection and the development of aquaculture require biological and ecological knowledge of the species, including growth rate, density and population structure. In this study we determined the rate of growth of juvenile $S$. gigas by direct methods in a natural protected area. Data was obtained through capture-markrecapture methods, allowing the natural foraging behavior, resource selection and dispersal of the animals.

\section{MATERIAL AND METHODS}

Study Site: Xel-Ha is located on the east coast of the Yucatan Peninsula (20 $10^{\prime} 15^{\prime \prime}$ $20^{\circ} 18^{\prime} 50^{\prime \prime} \mathrm{N}$ and $87^{\circ} 21^{\prime} 41^{\prime \prime}-87^{\circ} 21^{\prime} 15^{\prime \prime} \mathrm{W}$ ). The main oceanic current is the Caribbean Current (Organismo de Cuenca Península de Yucatán Dirección Técnica 2008). The area is characterized by medium wave energy and input of fresh water by underground rivers due to karstic conditions in the Peninsula (Organismo de Cuenca Península de Yucatán Dirección Técnica 2008). Xel-Ha is a creek that consists of a mix of fresh groundwater with seawater. The Inlet is connected to the Caribbean Sea by a $100 \mathrm{~m}$ wide channel and has a total surface of $14 \mathrm{Ha}$ with a center area and three appendices:
Bocana, North Arm and South Arm. Depth ranges from 1.75-4.0m (Organismo de Cuenca Península de Yucatán Dirección Técnica 2008). The climate in the region is warm and subhumid, with rains during summer and winter. The average annual temperature is $26^{\circ} \mathrm{C}$. Average annual rainfall is $1079 \mathrm{~mm}$ (Organismo de Cuenca Península de Yucatán Dirección Técnica 2008). The sampling site "Cueva" is located in the south-arm of the Inlet and includes a small bay surrounded by mangroves (Rhizophora mangle). Persistent upwelling of cold freshwater from underground caves, maintains a permanent thermo-and halocline $(1.25 \mathrm{~m})$. The site has a depth $1.5-3.5 \mathrm{~m}$. The bottom is composed of fine mud and sand formed of fragments of calcareous algae, mixed with rocks and dense isolated patches of macroalgae (Padina sp., Halimeda sp. Penicillus sp. Amphiroa sp. Acanthophora sp., Caulerpa sp., Dictyota sp.), decaying mangrove leaves and inverted jellyfish (Cassiopea sp.) may be found.

Population Parameters: Between April 2009 and January 2011, nine surveys were conducted at the site of Cueva in the Inlet of Xel-Ha sampling a total area $6000 \mathrm{~m}^{2}$. Three samplings were conducted during 2009, five in 2010 and one in January 2011. All organisms were collected in free-dive, by three divers during 3 hours. We used mark-recapture method, marking all individuals with a plastic Dymo ${ }^{\circledR}$ tag, bearing a consecutive number, which was fixed to the spire of the conch with a plastic cable binder. In order to evaluate the size distribution and growth rate, shell length (SL) was determined for each individual, as well as lip thickness, using a precision vernier caliper $(1 \mathrm{~mm})$. With the abundance data of recaptured and unmarked individuals we estimated population size using Schnabel's method (Schnabel 1938):

$$
\mathrm{N}_{\mathrm{t}}=\Sigma\left(\mathrm{C}_{\mathrm{t}} \mathrm{M}_{\mathrm{t}}\right) / \Sigma \mathrm{R}_{\mathrm{t}}
$$

Relative density of conch in Cueva was derived from population size. To determine the growth rate of conch per day, we only used 
the measurements of individuals which were recaptured for the first time after being marked in the previous sample $(n=706)$.

Environmental parameters: Parameters for dissolved oxygen $\left(\mathrm{O}_{2}\right)$, water temperature $\left({ }^{\circ} \mathrm{C}\right)$, salinity, total nitrogen $(\mathrm{N}$ total), total phosphates (P total), nitrate $\left(\mathrm{NO}_{3}^{-}\right)$and nitrite $\left(\mathrm{NO}_{2}^{-}\right)$, measured at the study site between February 2009 and September 2010 were provided as a courtesy of Xel-Ha Park and were used to aid interpretation of growth rates over time. Data was obtained through the laboratory LAB-ACAMA (Laboratorio de Análisis de Calidad de Agua y Medio Ambiente S.A. de C.V) applying the procedures specified by the Mexican Normative for Water quality NMXAA-26-SCFI-2001 for sampling and analysis.

Statistical Analysis: Using the program Infostat/S, we calculated the mean daily growth and standard deviation per size class $(<100 \mathrm{~mm}$, $100-149 \mathrm{~mm}, 150-199 \mathrm{~mm}$ and $\geq 200 \mathrm{~mm}$ ) and the average growth per day in each class over time. Growth data was subjected to analysis of variance (ANOVA) to detect significant differences in growth rate over time and between classes, with a confidence level of $95 \%$, followed by Tuckey's honestly significant difference test
(Saville 1990). Population structure was determined using histograms, with $10 \mathrm{~mm}$ intervals for size classes from $45-245 \mathrm{~mm}$. We calculated the percentage of individuals with flaring lip per size class. A correlation analysis using Pearson coefficient (Pearson 1896) between average growth rates from each sample and corresponding density was executed.

\section{RESULTS}

An average of $52.83 \%$, of a total of 1418 individuals tagged, was recaptured in each sample. The recapture success was lowest in October 2009 with $19.93 \%$ and highest in November 2010 with $74.74 \%$ (Table 1). Using the method of Schnabel, population size was estimated for each month as well as the relative density of conch in the Cueva. The relative average density was estimated at 0.1694 \pm 0.0996 ind. $\mathrm{m}^{-2}$, while the highest density was estimated for September 2010 with 0.3074 conches per square meter (Table 1).

Conches with SL less than $100 \mathrm{~mm}$ were the scarcest in Cueva representing less than 5\%, except in October 2009 and February 2010, when $11.32 \%$ and $42.81 \%$ were captured, respectively. Relative abundance was highest for the class of conch between 150

TABLE 1

Abundance, estimated abundance using Schnabel Method and density of S. gigas in Xel-há (Cueva)

\begin{tabular}{cccccccc} 
Sample & Ct & Rt & $\%$ Rt & Ut & Mt & Nt & Density (ind. $\left.\mathrm{m}^{-2}\right)$ \\
Apr. 09 & 127 & 0 & & 127 & 0 & & 0.0330 \\
Jun. 09 & 106 & 68 & 64.15 & 38 & 127 & 198 & 0.0826 \\
Oct. 09 & 306 & 61 & 19.93 & 245 & 165 & 496 & 0.1193 \\
Feb. 10 & 406 & 193 & 47.54 & 213 & 410 & 716 & 0.1510 \\
May. 10 & 382 & 195 & 51.05 & 187 & 623 & 906 & 0.1879 \\
Jul. 10 & 566 & 305 & 53.89 & 261 & 810 & 1128 & 0.3074 \\
Sep. 10 & 545 & 319 & 58.89 & 226 & 1071 & 1844 & 0.2370 \\
Nov. 10 & 479 & 358 & 74.74 & 121 & 1297 & 1422 & 0.2369 \\
Jan. 11 & 265 & 265 & & 0 & 1418 & 1422 & \\
\hline
\end{tabular}

1. $\mathrm{Ct}=$ Number of $S$. gigas caught in each sampling.

2. $\mathrm{Rt}=$ Number of recaptures in each sample.

3. $\% \mathrm{Rt}=$ Percentage of recapture per sample.

4. $\mathrm{Ut}=$ Number of untagged conch in each sample.

5. $\mathrm{Mt}=$ Total of marked animals at time.

6. $\mathrm{Nt}=$ Estimated population size using the Schnabel method. 


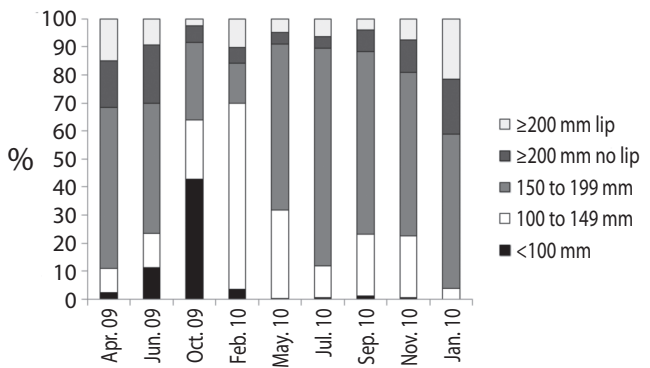

Fig. 1. Distribution of relative size class frequencies of queen conch $S$. gigas, sampled at Xel-ha, Mexico, showing the relative abundance $(\%)$ of animals which were $<100 \mathrm{~mm}$, between $100 \mathrm{~mm}$ and $149 \mathrm{~mm}$, between 150 and $199 \mathrm{~mm}$, $\geq 200 \mathrm{~mm}$ without lip and $\geq 200 \mathrm{~mm}$ with lip.

and $199 \mathrm{~mm}$, which made up an average of $51.18 \% \pm 19.57 \%$ of the population. Conch between 100 and $149 \mathrm{~mm}$ represented on average $22.13 \% \pm 18.69 \%$ of the population. Their abundance was highest in February 2010 with $66.50 \%$. Organisms with length $\geq 200 \mathrm{~mm}$ contributed on average $19.73 \% \pm 11.80 \%$ to the population. This class had the least variation in abundance compared with other classes.
$48.01 \% \pm 12.90 \%$ of the organisms $\geq 200 \mathrm{~mm}$ showed a formed lip (Fig. 1).

In April 2009, 94\% of the conchs were $\geq 145 \mathrm{~mm}$ (Fig. 2). The size classes with highest frequency of abundance in that month were the animals with SL between $215 \mathrm{~mm}$ and $225 \mathrm{~mm}$, and the animals between $185 \mathrm{~mm}$ and $195 \mathrm{~mm}$, making up $26 \%$ of the population. In June 2009 a significant increase in organisms $<145 \mathrm{~mm}$ was observed, representing $24 \%$ of the organisms sampled. Throughout October 2009 and February 2010 abundance of individuals $<145 \mathrm{~mm}$ increased dramatically, recording $63.42 \%$ and $67.73 \%$. Modal class in October was $85-95 \mathrm{~mm}(16.34 \%)$ and $125-135 \mathrm{~mm}$ (17.24\%) in February. In May the number of conch $<145 \mathrm{~mm}$ captured decreased again, with $22.5 \%$ and the modal class were juveniles between $145 \mathrm{~mm}$ and $155 \mathrm{~mm}$, which represented $25.65 \%$ of the population. Modal class shifted in July to the class of $155-165 \mathrm{~mm}$ $(22.79 \%)$ and the abundance of conch $<145 \mathrm{~mm}$ continued to decline, reaching $9.35 \%$. In September of the same year, we could detect the emergence of new recruits, with $21.65 \%$ of conch $<145 \mathrm{~mm}$ and modal class was 185 $195 \mathrm{~mm}(16.88 \%)$. Recruits kept emerging

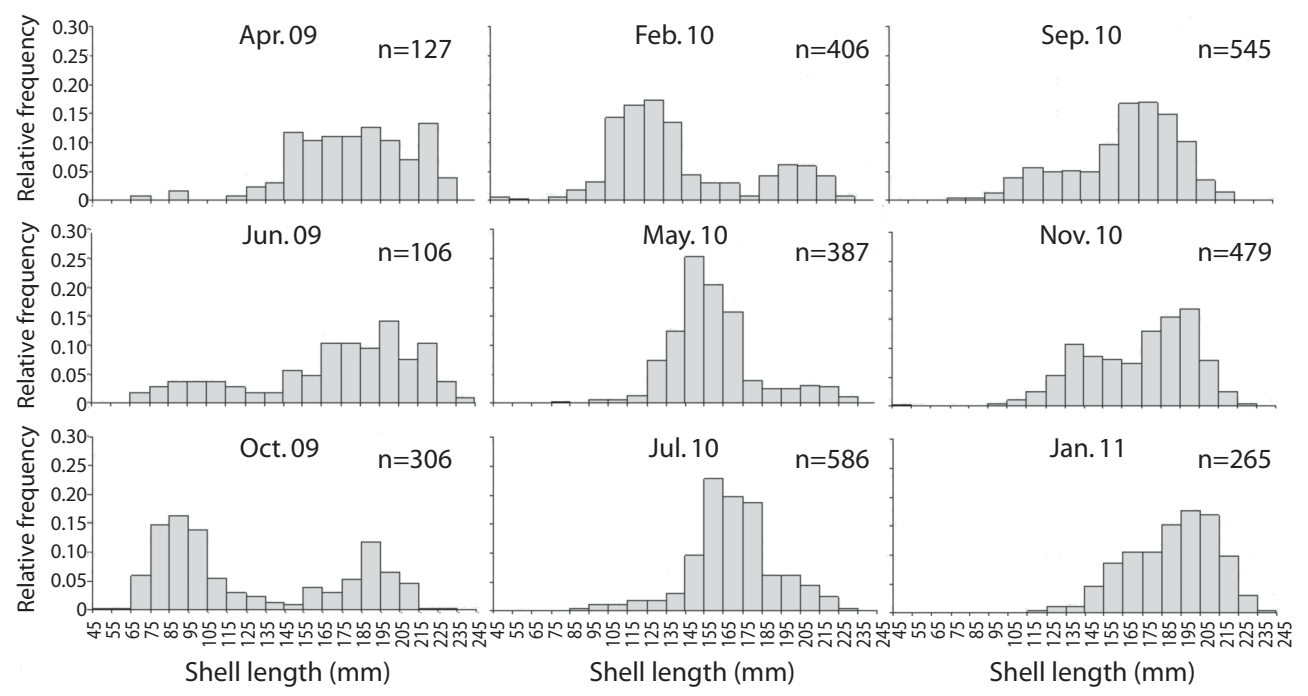

Fig. 2. Histograms showing relative frequency of abundance per size class, modal progression and recruitment patterns of queen conch S.gigas sampled at Xel-Ha, Mexico, between April 2004 and January 2011. 
throughout November, with $20.05 \%$ of the animals $<145 \mathrm{~mm}$ and modal class shifted to 195 205mm (16.7\%). In January 2011 no conchs smaller than $115 \mathrm{~mm}$ were found and $97.37 \%$ of the sampled population had a size $\geq 145 \mathrm{~mm}$ and the class with highest frequency was 195205mm (17.74\%).

For the growth rate analysis the population was divided into 4 size classes (Fig. 3). Growth was highest in animals of $100-149 \mathrm{~mm}(\mathrm{n}=306)$ with an average growth of $0.27 \pm 0.1 \mathrm{~mm}^{\text {day }}{ }^{-1}$. The animals of this size class showed at the same time the greatest variation in growth rates, with values between 0.01 and $0.63 \mathrm{~mm}$ day $^{-1}$. The growth rate had normal distribution (Shapiro-Wilks $\mathrm{p}=0.0856$ ) and the median coincided with the mean. In juvenile conch smaller than $100 \mathrm{~mm}(\mathrm{n}=96)$ we calculated a growth rate of $0.24 \pm 0.05 \mathrm{~mm}^{\text {day }}{ }^{-1}$. Growth rate decreased to $0.18 \pm 0.08 \mathrm{~mm} \mathrm{day}^{-1}$ in the class of $150-199 \mathrm{~mm}(\mathrm{n}=268)$ and was lowest with $0.08 \pm 0.07 \mathrm{~mm} \mathrm{day}^{-1}$ in conch with a size $\geq 200 \mathrm{~mm}(\mathrm{n}=36)$ (Fig. 3$)$. The growth rate showed significant differences between size classes (ANOVA F $3,705=80.08, \mathrm{p}_{3,0.0001)}$, but was similar between the classes $<100 \mathrm{~mm}$ and 100-149mm (Tuckey, $\mathrm{p}<0.05$ ).

The growth showed significant differences over time in classes of $<100 \mathrm{~mm}\left(\mathrm{~F}_{5,95}=8.01\right.$, $\mathrm{p}<0.0001), 100 \mathrm{~mm}$ to $149 \mathrm{~mm}\left(\mathrm{~F}_{7,305}=36.98\right.$, $\mathrm{p}<0.0001)$ and $150 \mathrm{~mm}$ to $199 \mathrm{~mm}\left(\mathrm{~F}_{7,267}=\right.$ $9.14 ; \mathrm{p}<0.0001)$. There were no significant differences in the class of animals $\geq 200 \mathrm{~mm}$ $\left(\mathrm{F}_{6,35}=1.46 ; \mathrm{p}=0.2262\right)$. The highest growth rate was observed in May 2010, while the lowest growth was observed in October 2009 and November 2010 (Fig. 4 and Table 2).

No significant association was detected between growth rate and the relative density of conch $(\mathrm{R}=0.17 ; \mathrm{p}=0.69)$.

Xel-Ha Park occasionally carries out surveys to monitor water quality. The results corresponding to the area of Cueva are shown in Figure 5.

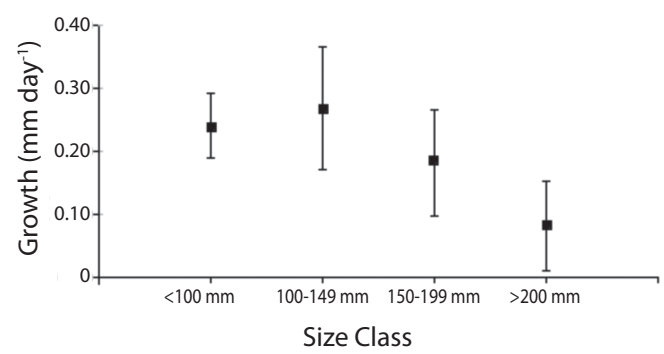

Fig. 3. Mean growth rate $\left(\mathrm{mm} d a y^{-1}\right)$ and its standard deviation (Bars) of queen conch S.gigas with Shell length $<100 \mathrm{~mm}$, between $100 \mathrm{~mm}$ and $149 \mathrm{~mm}$, between 150 and $199 \mathrm{~mm}$, and $\geq 200 \mathrm{~mm}$, sampled at Xel-Ha, Mexico.

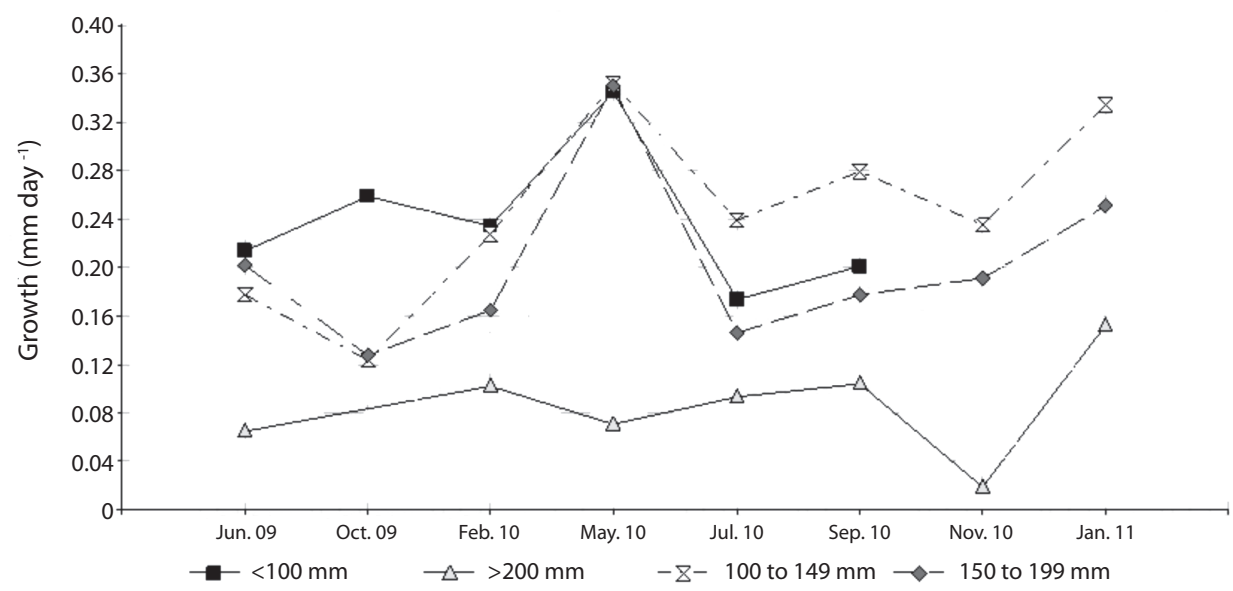

Fig. 4. Average growth rate $\left(\mathrm{mm} \mathrm{day}^{-1}\right)$ over time in pink queen conch S.gigas with a shell length of $<100 \mathrm{~mm}, 100 \mathrm{~mm}$ to $149 \mathrm{~mm}, 150 \mathrm{~mm}$ to $199 \mathrm{~mm}$ and $\geq 200 \mathrm{~mm}$, at Cueva (Xel-Ha, Mexico). 
TABLE 2

Average growth (mm day-1) of queen conch S.gigas with a shell length of $<100 \mathrm{~mm}, 100 \mathrm{~mm}$ to $149 \mathrm{~mm}$, $150 \mathrm{~mm}$ to $199 \mathrm{~mm}$ and $\geq 200 \mathrm{~mm}$, over time, at Xel-Ha, Mexico

\begin{tabular}{cccccccccc} 
Size Class / Growth & Jun. 09 & Oct. 09 & Feb. 10 & May 10 & Jul. 10 & Sep. 10 & Nov. 10 & Jan. 11 \\
$<100(\mathrm{~mm})$ & 0.21 & 0.26 & 0.23 & 0.35 & - & 0.17 & 0.2 & - \\
100 to $149(\mathrm{~mm})$ & 0.18 & 0.12 & 0.23 & 0.35 & 0.24 & 0.24 & 0.28 & 0.33 \\
150 to $199(\mathrm{~mm})$ & 0.2 & 0.13 & 0.16 & 0.35 & 0.19 & 0.15 & 0.18 & 0.25 \\
$\geq 200 \mathrm{~mm}$ & 0.06 & - & 0.1 & 0.07 & 0.02 & 0.09 & 0.1 & 0.15 \\
\hline
\end{tabular}
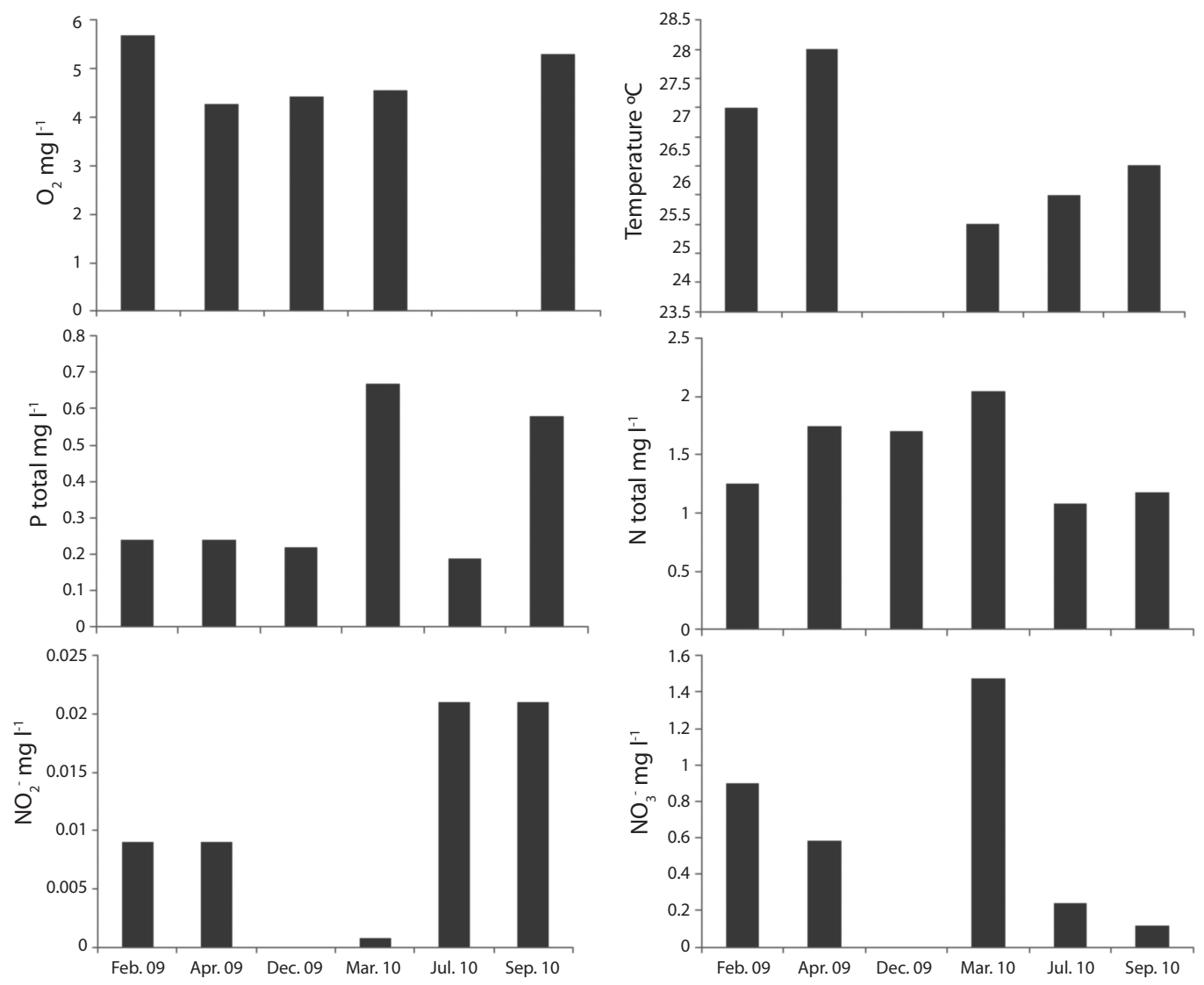

Fig. 5. Water quality parameters, showing surface temperature, dissolved oxygen at the surface, total nitrogen ( $\mathrm{N}$ total), Nitrate (NO), Nitrite (NO) and total phosphate (total P) at Xel-Ha's Cueva. Data was provided by courtesy of the administration of Xel-Ha Park.

\section{DISCUSSION}

In the present work conch larger than $210 \mathrm{~mm}$ were present in all samples and a total of 268 observations could be made, representing $8.42 \%$ of the population. Aldana-Aranda et al. (2005) reported the absence of animals larger than $210 \mathrm{~mm}$ at Cueva in the majority of the samples taken in a study conducted between 2001 and 2002. Xel-Ha initiated the Monitoring Program, as well as the actions for conservation and rehabilitation of the queen conch in October 2001. The conch population of Xel-Ha has grown in size and more large and 
juvenile conch could be found than in previous studies, suggesting that the park of Xel-Ha is providing effective protection for the species.

Apparent recruitment was detected throughout most of the year, but was highest from June 2009 to May 2010 and September 2010 to November 2010. Aldana-Aranda et al. (2003) documented recruitment throughout most of the year and high recruitment during October 2001. In a subsequent study Aldana-Aranda et al. (2005) documented higher recruitment in October 2002, February 2002 and February 2003, consistent with recruitment peaks observed in this study, in February and October.

In the present study population structure was: $<100 \mathrm{~mm}=7.0 \% ; 100-149 \mathrm{~mm}=22.1 \%$; $150-199 \mathrm{~mm}=51.2 \% ; \geq 200 \mathrm{~mm}=19.7 \%$. Aldana-Aranda et al. (2005) reported $4.2 \%$ of the population $<100 \mathrm{~mm}, 23.8 \%$ in the class of $100-150 \mathrm{~mm}, 51.2 \%$ conch $150-200 \mathrm{~mm}$ and $23.4 \%$ of the population $>200 \mathrm{~mm}$ in the period from November 2001 to August 2003, applying the same methodology. It can be noted that relative proportion of adults and juveniles has remained similar in comparison with previous studies, despite the increase in numbers of individuals, indicating the population is in an equilibrium state.

In the present study, the population was small initially; however, we observed substantial recruitment of juveniles from October 2009 onwards, reaching a maximum density of 0.3074 conches per square meter in September 2010. Aldana-Aranda et al. (2005) estimated a population size of $632.15 \pm 49.40$ individuals in the period from 2001 to 2003, using Schnabel's method. Peel et al. (2010) reported average catches of 82.09 conches per sample in the period from January 2004 to January 2008 at the sampling site Cueva. The observed population growth was attributed to increased recruitment of juveniles.

The Density at Xel-Ha's Cueva is high, compared to other areas in the Caribbean (Table 3). The densities documented at Cueva were higher than densities reported for Alacranes Reef, where conch fishery was banned in 1988 (Pérez-Pérez \& Aldana-Aranda 1998, Ríos-Lara et al. 1998, Pérez-Pérez \& AldanaAranda 2000, Pérez-Pérez \& Aldana-Aranda 2003), ranging from 0.0047 to 0.018 conch $\mathrm{m}^{-2}$. They were also higher than the densities reported for the two most important commercial

TABLE 3

Average densities of $S$. gigas in the Caribbean

\begin{tabular}{lcc}
\multicolumn{1}{c}{ Author, Year } & Location & Density (ind. $\mathrm{m}^{-2}$ ) \\
Ríos-Lara et al. 1998 & Alacranes Reef, Yucatán, México & 0.0047 \\
Pérez-Pérez \& Aldana-Aranda 1998 & Alacranes Reef, Yucatán, México & 0.0072 \\
Pérez-Pérez \& Aldana-Aranda 2000 & Alacranes Reef, Yucatán, México & 0.0084 \\
Pérez-Pérez \& Aldana-Aranda 2003 & Alacranes Reef, Yucatán, México & 0.018 \\
De Jesús-Navarrete et al. 1992 & Punta Gavilán, Quintana Roo, México & 0.003 \\
De Jesús-Navarrete \& Oliva-Riviera 1997 & Punta Gavilán, Quintana Roo, México & $0.0052 \pm 0.0023$ \\
INP-SAGARPA 2008 & Banco Chinchorro, Quintana Roo, México & $0.0211 \pm 0.035$ \\
INP-SAGARPA 2008 & Banco Cozumel, Quintana Roo, México & $0.0079 \pm 0.01653$ \\
Berg \& Glazer 1991 & Florida Keys, Florida, USA & $0.000109-0.000298$ \\
Friedlander et al. 1994 & Virgin Islands, USA & 0.00171 \\
Stoner \& Ray 1993 & Exuma Cays, Bahamas & 0.2 \\
Stoner \& Schwarte 1994 & Lee Stocking Island, Bahamas & $0.0018-0.0088$ \\
Stoner 1996 & Exuma Cays (unfished zones), Bahamas & $0.0034-0.0147$ \\
Stoner 1996 & Exuma Cays (fished zones), Bahamas & $0.00022-0.0088$ \\
Stoner \& Ray 1996 & Exuma Park,Exuma Cays, Bahamas & 0.027 \\
Posada et al. 1999 & Jaragua National Park, Dominian Republic & $0.0004-0.01142$ \\
\hline
\end{tabular}


queen conch fishery grounds in Quintana Roo, Banco Chinchorro $\left(0.0211 \pm 0.035\right.$ ind $\left.^{-2}\right)$ and Banco Cozumel $\left(0.0079 \pm 0.01653\right.$ ind $\left.\mathrm{m}^{-2}\right)$. In Punta Gavilán, a coastal area without commercial fishing, densities range from 0.003 to 0.0052ind. $\mathrm{m}^{-2}$ (De Jesús-Navarrete et al. 1992, De Jesús-Navarrete \& Oliva-Riviera 1997). Berg \& Glazer (1994) reported in the Florida Keys, USA, densities between 0.000109ind. $\mathrm{m}^{-2}$ and 0.000298 ind. $\mathrm{m}^{-2}$, where a permanent fishing ban has been implemented since 1985 and sanctuaries with surveillance have been created due to the rapid depletion of stocks of Queen Conch. The density at Xel-Ha's Cueva is similar to the relatively natural populations in the Exuma Cays (Table 4) (Stoner \& Ray 1993, Stoner 1996) and can be compared to the highdensity aggregation nursery grounds (Stoner \& Ray 1993, Stoner \& Lally 1994) in terms of population structure and density.

The growth rate of juvenile conch in Cueva was high in comparison with those mentioned by other studies (Table 4). De Jesús-Navarrete (2001) obtained an average increase of $3.21 \mathrm{~mm}$ month $^{-1}\left(\sim 0.1052 \mathrm{~mm} \mathrm{day}^{-1}\right)$ in Punta Gavilán and $2.30 \mathrm{~mm} \mathrm{month}^{-1}\left(\sim 0.075 \mathrm{~mm} \mathrm{day}^{-1}\right)$ in Banco Chinchorro, maintaining conch in enclosures at density of 0.4 ind. $\mathrm{m}^{-2}$. In other areas of the Caribbean similar increases were observed (Randall 1964, Alcolado 1976, Brownell 1977, Ray \& Stoner 1994). Growth rates measured during this study were comparable to other studies conducted under natural conditions using mark-recapture methods. Gibson et al.
(1983) determined a rate of $7.2 \mathrm{~mm}$ month $^{-1}$ $\left(\sim 0.236 \mathrm{~mm} \mathrm{day}^{-1}\right)$ in Belize, while in Venezuela an increase of $15 \mathrm{~mm}$ month $^{-1}\left(\sim 0.492 \mathrm{~mm} \mathrm{day}^{-1}\right)$ was measured (Weil \& Laughlin 1984) and in Punta Gavilán, juveniles grew an average of $10 \mathrm{~mm} \mathrm{month}^{-1}\left(\sim 0,327 \mathrm{~mm} \mathrm{day}^{-1}\right)$ (De JesúsNavarrete \& Oliva-Rivera 1997). The growth rate of juvenile queen conch at Xel-Ha's Cueva was comparable to the growth measured by Moreno de la Torre \& Aldana-Aranda (2007) under experimental conditions, using artificial diets, who obtained an increase of 0.16$0.23 \mathrm{~mm} \mathrm{day}^{-1}$. However, the conch used in their study had an initial size inferior to $40 \mathrm{~mm}$ and were smaller than the organisms in the present study.

Growth rates declined in the $150-199 \mathrm{~mm}$ size class and tended towards null in conch $\geq 200 \mathrm{~mm}$ (Fig. 3). Conches grow in shell length only until maturation. At this time the flared shell-lip is formed. Subsequent shell growth occurs as a progressive thickening of the shelllip (Appeldoorn 1988). Most conch reach sexual maturation when the shell lip is thicker than 5mm (Appeldorn 1988, Aldana-Aranda \& Frenkiel 2007). Shell morphology and maximum size can vary considerably (Alcolado 1976, Appeldoorn 1994) and may not represent a good indicator for maturity (Aldana-Aranda \& Frenkiel 2007). The maximum SL observed at Xel-Ha in our study was $239 \mathrm{~mm}$ and less than the half of the organisms in the $\geq 200 \mathrm{~mm}$ class had developed a flaring lip. It may be deduced that more than half of the conch

TABLE 4

Comparative Table of mean growth rates of $S$. gigas

\begin{tabular}{|c|c|c|c|c|}
\hline Author, Year & Location & Method & $\begin{array}{l}\text { Growth rate } \\
\left(\mathrm{mm} \mathrm{month}^{-1}\right)\end{array}$ & $\begin{array}{l}\text { Growth rate } \\
\left(\mathrm{mm}^{\text {day }}{ }^{-1}\right)\end{array}$ \\
\hline Randall 1964 & Virgin Islands, USA & Enclosure & 4.16 & $\sim 0.136$ \\
\hline Alcolado1976 & Cuba & Enclosure, different environments & 3.3 & $\sim 0.108$ \\
\hline Brownell 1977 & Florida Keys, USA & Enclosure & 4.5 & $\sim 0,147$ \\
\hline Gibson et al. 1983 & Belize & Mark-Recapture & 7.2 & $\sim 0.236$ \\
\hline Weil \& Laughlin 1984 & Venezuela & Mark-Recapture & 15 & $\sim 0.492$ \\
\hline Ray \& Stoner 1994 & Exuma Cays, Bahamas & Enclosure & - & $0.058-0.139$ \\
\hline De Jesús-Navarrete \& Oliva-Rivera 1997 & Punta Gavilán, México & Mark-Recapture & 10 & $\sim 0,327$ \\
\hline De Jesús-Navarrete 2001 & Banco Chinchorro, México & Enclosure, different environments & 3.21 & $\sim 0.1052$ \\
\hline De Jesús-Navarrete 2002 & Punta Gavilán, México & Enclosure, different environments & 2.30 & $\sim 0.075$ \\
\hline Moreno de la Torre \& Aldana-Aranda 2005 & México & Laboratory conditions, artificial diet & - & $0.16-0.23$ \\
\hline
\end{tabular}


$\geq 200 \mathrm{~mm}$ are still immature and may represent some considerable growth.

Growth rate of the queen conch showed large individual variations, especially in animals of the class of $100-149 \mathrm{~mm}$. Alcolado (1976) showed that growth may vary according to environmental variability between sites; however, the study area of the Cueva is a relatively small area, making it more likely that all organisms have been exposed to the same conditions. Ray \& Stoner (1994) suggested that juvenile conch are vulnerable to predation and may choose lower quality habitat in terms of resources, compromising maximum ingestion and growth, by aggregating or sheltering in dense vegetation, to reduce the risk of predation and increase survival probabilities. The high growth rate of juvenile conch in Xel-Ha and the large variations in individuals likely reflects the natural conditions of foraging and aggregation.

We could detect significant variation in the rate of growth over time (Fig. 4). There was an increase in nutrients important for production of biomass ( $\mathrm{P}, \mathrm{N}$ and $\mathrm{NO}$ ) in the sample of March 2010, for which it is likely that the increase in growth rate during May 2010 might be the result of higher primary productivity.

We conclude that the direct method is useful for the assessment of growth in juvenile $S$. gigas and that growth in natural conditions is higher than in enclosures and aquaculture systems. This information may be applied to fishery management as well as to rehabilitation programs and aquaculture.

\section{ACKNOWLEDGMENTS}

We gratefully acknowledge financial support by CONACYT through Grant Conacyt SEP 24210 Connectivity of the Conch in the Caribbean, CONACYT student scholarship (374674/243375) and CINVESTAV-IPN. Also we thank Xel-Ha Park's administration, Elizabeth Lugo Monjarras and Ricardo Saenz Morales for providing unlimited access and logistic support during our field work. We thank Xel-Ha staff Enrique May, Teresa Rivas, Angel Chavarria and Mario Hoil for their field support.

\section{RESUMEN}

La Ensenada de Xel-Ha es usada como parque para ecoturismo y representa un santuario para la conservación del caracol rosado. El incremento en la presión de la pesca ha llevado a la inclusión de esta especie en CITES. Mucho del conocimiento acerca del crecimiento del caracol rosado ha sido generado a través de la acuicultura, encierros oceánicos o usando estimaciones derivadas de las dinámicas poblacionales. En este estudio estimamos la tasa de crecimiento de Strombus gigas juvenil en un área natural protegida, por métodos directos durante el período de abril 2009 a enero 2011. Los datos fueron obtenidos por muestras de captura-marca-recaptura. Un total de 1418 individuos fueron marcados y el crecimiento de 714 caracoles fue analizado. La talla de la población y la densidad relativa fue estimada usando el método de Schnabel. La densidad promedio relativa fue estimada en $0.1694 \pm 0.0996$ ind. $\mathrm{m}^{-2}$, mientras que la densidad más alta fue estimada para septiembre 2010 con 0.3074 ind. $\mathrm{m}^{-2}$. La tasa de crecimiento más alta $\left(0.27 \pm 0.10 \mathrm{~mm} \mathrm{día}^{-1}\right)$ fue detectada en juveniles con una talla inicial entre $100-149 \mathrm{~mm}$, seguida por juveniles $<100 \mathrm{~mm}$, con un incremento de $0.24 \pm 0.05 \mathrm{~mm} \mathrm{día}^{-1}$. La tasa de crecimiento disminuyó para individuos con una talla inicial entre $150-199 \mathrm{~mm}\left(0.18 \pm 0.09 \mathrm{~mm} \mathrm{día}^{-1}\right)$ y para organismos $>200 \mathrm{~mm}\left(0.08 \pm 0.07 \mathrm{~mm} \mathrm{día}^{-1}\right)$. La variabilidad en la tasas de crecimiento fue alta en individuos entre 100-149mm y mostró diferencias estacionales; con la tasa de crecimiento más alta en mayo 2010. El reclutamiento de juveniles más alto se dio en octubre 2009 y en febrero 2010. La población de Xel-Ha ha crecido en tamaño y se pudo encontrar más adultos y juveniles que en estudios anteriores, lo que demuestra que el Parque de Xel-Há está funcionando como un santuario para la conservación del caracol rosado del Caribe en la Riviera Maya de México. La tasa de crecimiento de juveniles en Xel-Ha es alta y presenta grandes variaciones en los individuos, lo cual refleja las condiciones naturales de la alimentación y la agregación. Las diferencias estacionales en las tasas de crecimiento pueden estar asociadas con la calidad del agua y la disponibilidad de nutrimentos para la producción primaria. Concluimos que el método directo es útil parar monitorear el crecimiento en juveniles de $S$. gigas y que el crecimiento en condiciones naturales es mayor que en sistemas de acuicultura. Esta información puede ser aplicada al manejo de pesquerías así como también en programas de rehabilitación y acuicultura.

Palabras clave: Strombus gigas, Área Marina Protegida, densidad poblacional, crecimiento, marcaje-recaptura, reclutamiento

\section{REFERENCES}

Alcolado, P.M. 1976. Crecimiento, variaciones morfológicas de la concha y algunos datos biológicos del 
cobo Strombus gigas L. (Mollusca, Mesogastrópoda). Acad. Cien. Cuba Ser. Oceanol. 34: 36.

Aldana-Aranda, D. \& L. Frenkiel. 2007. Lip thickness of Strombus gigas (Mollusca:Gastropoda) versus maturity: A management measure. Proc. Gulf Carib. Fish. Inst.58: 431-442.

Aldana-Aranda, D., M. Sánchez-Crespo, V. Patiño-Suárez, A. George-Zamora, A.E. Carillo \& S. Pérez. 2003. Abundancia, frecuencia de tallas y distribución espacial del caracol rosa Strombus gigas en el parque XelHa, México. P 33-37. In D. Aldana-Aranda. (ed.). El caracol Strombus gigas: Conocimiento Integral para su Manejo Sustentable en el Caribe. CYTED, Merida, Yucatán, México.

Aldana-Aranda, D., M. Sánchez-Crespo, P. ReynagaAlvarez, V. Patiño-Suárez, A. George-Zamora \& E.R. Baqueiro-Cárdenas. 2005._Crecimiento y temporada reproductiva del caracol rosa Strombus gigas en el parque Xel-Há, México. Proc. Gulf Carib. Fish. Inst.56: 741-754.

Appeldoorn, R.S. 1988. Age determination, growth, mortality and age of first reproduction in adult queen conch, Strombus gigas L., off Puerto Rico. Fish. Res. 6: $363-378$

Appeldorn, R.S. 1994. Queen conch management and research: status, needs and priorities. p. 301-319. In Appeldorn, R. S. \& B. Rodriguez, (eds.). Strombus gigas Queen Conch Biology, Fisheries and Mariculture. Fundación Científica Los Roques, Caracas, Venezuela.

Baquiero-Cardenas, E.R. 1997. The molluscan fisheries of Mexico, p. 39-49. In MacKenzie, C.L Jr., V.G. Burrell, A. Rosenfield \& W.L. Hobart (eds.) NOAA Tech. Rep. NMFS 129: The History, Present Condition and Future of the Molluscan Fisheries of North and Central America and Europe. U.S. Dept. of Commerce.

Berg, C.J. 1976. Growth of queen conch, Strombus gigas, with a discussion of the particularity of its mariculture. Mar. Biol. 34: 1-36.

Berg, C.J. \& R.A.Glazer. 1994. Current research on queen conch (Strombus gigas) in Florida Waters. Proc. Gulf Carib. Fish. Inst.40: 303-306.

Brownell, W.N., C.J. Berg, Jr., \& K.C. Haines. 1977. Fisheries and aquaculture of the queen conch, Strombus gigas, in the Caribbean. FAO Fish. Rep. 200: 59-69.

Brownell, W.N. \& J.M. Stevely. 1981. The biology, fisheries, and management of the queen conch, Strombus gigas. Mar. Fish. Rev., U.S. Dept. Comm. 43:1- 12.
Chakalall, B. \& K.L. Cochrane. 1997. The queen conch fishery in the Caribbean - An approach to responsible fisheries management. Proc. Gulf Carib. Fish. Inst. 49:531-554.

Davis, M. 2000. Queen conch (Strombus gigas) culture techniques for research stock enhancement and growout markets, p 127-159. In Fingerman, M. \& R. Nagabhushanam (eds.). Recent advances in marine biotechnology Vol.4: Aquaculture Part A Seaweeds and Invertebrates. Science Publishers, Inc., New Hampshire, USA.

De Jesús-Navarrete, A., E. González, J. Oliva, A. Pelayo \& G. Medina. 1992. Advances over some ecological aspects of queen conch Strombus gigas, L. in the southern Quintana Roo, Mexico. Proc. Gulf Carib. Fish. Inst.45: 18-24.

De Jesús-Navarrete, A. \& J.J.Oliva-Riviera. 1997. Density, growth, and recruitment of the queen conch Strombus gigas L. (Gastropoda: Strombidae) in Quintana Roo, Mexico. Rev. Biol. Trop. 45: 797-801.

De Jesús-Navarrete, A. 2001. Crecimiento del caracol Strombus gigas (Gastropoda: Strombidae) en cuatro ambientes de Quintana Roo, México. Rev. Biol. Trop., 49: 85-91.

Friedlander, A., R.S. Appeldoorn \& J. Beets. 1994. Spatial and temporal variations in stock abundance of queen conch, Strombus gigas, in the U.S. Virgin Islands, p. 51-60 In R.S. Appeldoorn \& B. Rodriguez (eds.). Queen Conch Biology, Fisheries and Mariculture, Fundacion Cientifica Los Roques, Caracas, Venezuela.

Gibson, J, S. Strasdine \& K. Gonzales. 1983. The status of the conch industry of Belize. Proc. Gulf Carib. Fish. Inst. 35: 99-107.

Glazer, R.A. \& R. Jones. 1997. Temporal factors influencing survival of queen conch outplants. Final Report. U.S. Fish and Wildlife Service Project: 1-58

INP-SAGARPA. 2008. Dictamen Técnico: Estimación de biomasa explotable de Strombus gigas en los bancos abiertos a la pesca en Quintana Roo, México: Banco Chinchorro y Banco de Cozumel. Temporada de Captura 2008-2009.

Moreno de la Torre, R. \& D. Aldana-Aranda. 2007. Crecimiento y eficiencia alimenticia del caracol rosado Strombus gigas (Linnaeus, 1758) juvenil alimentado con nueve alimentos balanceados conteniendo diferentes niveles de proteína y energía. Proc. Gulf Carib. Fish. Inst.58: 463-467 
Pearson, K. 1986. Mathematical Contributions to the Theory of Evolution.--On a Form of Spurious Correlation Which May Arise When Indices Are Used in the Measurement of Organs . Proc. R. Soc. Lond. 60:489-498.

Peel, J.R., R. Saenz, E. May, J. Montero \& D. AldanaAranda. 2010. Importance of a Marine Protected Area in the Mexican Caribbean on the Conservation of the Endangered Species of Queen Conch, Strombus gigas. GCFI Book of Abstract 63: 39.

Pérez-Pérez, M. \& D. Aldana Aranda. 1998. Análisis preliminar de la densidad del caracol rosado (Strombus gigas) en el arrecife Alacranes Yucatán, México. Proc. Gulf Carib. Fish. Inst.50: 49- 65.

Pérez-Pérez, M. \& D. Aldana-Aranda. 2000. Distribución, abundancia, densidad y morfometría de Strombus gigas (Mesogastropoda:Strombidae) en el Arrecife Alacranes Yucatán, México. Rev. Biol. Trop. 48: 51-57.

Pérez-Pérez, M. \& D. Aldana-Aranda. 2003. Actividad de Strombus gigas (Mesogastropoda: Strombidae) en diferentes hábitats del arrecife Alacranes, Yucatán. Rev.Biol. Trop. 51: 119-126.

Posada, J.M., R.I. Mateo \& M. Nemth. 1999. Occurrence, abundance and length frequency distribution of queen conch, Strombus gigas (Gasteropoda) in shallow waters of the Jaragua National Park, Dominican Republic. Carib. J.of Sci. 35: 70-82.

Randall, J.E. 1964. Contribution to the biology of the queen conch Strombus gigas. Bull. Mar. Sci. Gulf Carib. 14:246-295.

Rathier, I. 1987. Etat d'avancement des recherches sur l'élevage du lambi Strombus gigas in Martinique. Proc. Gulf Carib. Fish. Inst 38: 336-344
Ray, M. \& A.W. Stoner. 1994. Experimental analysis of growth and survivorship in a marine gastropod aggregation: Balancing growth with safety in numbers. Mar. Ecol. Prog. Ser 105: 47-59.

Ríos-Lara, G.V., K. Cervera-Cervera, J.C. Espinoza-Méndez, M. Pérez-Pérez, C. Zetina-Moguel, \& F. Chable Ek. 1998. Estimación de las Densidades de langosta espinosa (Panulirus argus) y caracol rosa (Strombus gigas) en el área central del Arrecife Alacranes, Yucatán, México. Proc. Gulf Carib. Fish. Inst.50:104-127.

Saville, D.J. 1990. Multiple Comparison Procedures: The Practical Solution. Am. Stat. 44:174-180.

Schnabel, Z. E. 1938. The estimation of the total fish population of a lake. Amer. Math. Month. 45:348-352.

Stoner, A.W. \& K.C. Schwarte. 1994. Queen conch, Strombus gigas, reproductive stocks in the central Bahamas: distribution and probable sources. Fish. Bull., U.S. 92:171-179.

Stoner, A.W. 1996. Status of queen conch research in the Caribbean. Proceedings International Queen Conch Conference Strombus gigas: 23-39.

Stoner, A.W. \& M. Ray. 1993. Aggregation dynamics in juvenile queen conch (Strombus gigas): population structure, mortality, growth and migration. Mar Biol. 116:571-582.

Stoner, A.W. \& M. Ray. 1996. Queen conch (Strombus gigas) in fished and unfished

locations of the Bahamas: effects of a marine fishery reserve on adults, juveniles, and larval production. Fish. Bull. 94:551-565.

Weil, M. \& G. Laughlin. 1984. Biology, population dynamics, and reproduction of the queen conch, Strombus gigas Linné., in the Archipielago de los Roques National Park. J. Shellfish Res. 4:45-62. 
